\title{
Web 2.0 Technologies and Building Online Learning Communities: Students’ Perspectives
}

\author{
Mariam Mousa Matta Abdelmalak \\ New Valley College of Education, Assiut University, Egypt
}

\begin{abstract}
The purpose of this action research was to explore students' perspectives regarding using Web 2.0 technologies to develop a community of learners. The course described in this study was a fully online course in an Educational Learning Technologies master's program at a medium-sized university in the U.S. Southwest. A variety of Web 2.0 tools (Twitter, Google Docs, Skype, blogs, and wikis) were used throughout the course to enhance students' sense of community. The methods of data collection in this study included students' reflective journaling activities, the researcher's journal and field notes, and students' comments on each other's reflections. Students indicated that using Google Docs, wikis, blogs, and Twitter gave them a sense of a learning community while using Skype did not. Google Docs and wikis had the most impact on students' sense of a learning community in the course. Findings suggest that faculty interested in building learning communities in online environments need to use variety of Web 2.0 technologies in order to make students aware of those technologies' promise for supporting communication.
\end{abstract}

\section{Introduction}

Building learning communities is an important topic for online learning because of the current value placed on social learning in general and because of continuing questions about the capacity of online learning environments to prompt true communities. The literature on distance education highlights many strategies to help online students build a sense of community. Much of the writing on the communitybased approach to online learning — that is, related to developing and sustaining it - describes the use of asynchronous discussions (e.g., Clarke \& Kinne, 2012; Moisey, Neu, \& Cleveland-Innes, 2008; Buckingham, 2003; Brook \& Oliver, 2003), introductory activities (e.g., Dixon, Crooks, \& Henry, 2006), and group contracts (e.g., Murphy, Mahoney, \& Harvell, 2000) as the means by which this community is developed. Few studies explored the role Web 2.0 technologies play in the development of online learning communities. Additionally, little is known about students' perspectives regarding using Web 2.0 technologies to develop these communities. This paper describes practitioner experiences of using Web 2.0 technologies to develop a community of learners among graduate online students and discusses students' perspectives in using these tools. 
Web 2.0 Technologies and Building Online Learning Communities: Students’ Perspectives

\section{Literature Review}

\section{Online Learning Communities}

Building learning communities is critical to student success in online environments. Community is widely accepted as a sense rather than a tangible entity (Wiesenfeld, 1996). Sense of community has been defined as "a sense that members have a belonging, members matter to one another and to the group and a shared faith that members' needs will be met through their commitment to be together" (McMillan \& Chavis, 1986, p. 9). To develop a successful online course, many scholars (e.g., Hiltz, 1998; Russell, 1999; Palloff \& Pratt, 2007) suggest that building and sustaining an online learning community is crucial and necessary. Students in asynchronous distance classes work at computers that are miles apart and at varying times of the day, resulting in a feeling of isolation. Fostering online learning communities can help diminish that sense of isolation and, hence, heighten the educational experience of participants (Palloff \& Pratt, 2007; Rovai, 2002; Bonk \& Wisher, 2000; Hiltz, 1998). Therefore, building learning communities should be a primary goal for online instructors (Palloff \& Pratt, 2007; Hiltz, 1998). However, it is important to note that the desired outcome from the formation of a learning community is not only the creation of a social community but also the ability of the instructor to convey knowledge about the content and for the community to collaboratively make meaning from that content (Palloff \& Pratt, 2007).

Research supports the fact that the students' sense of community is important to the learning process. Studies have connected students' experiences in learning communities with positive learning outcomes, satisfaction with the learning experience (Richardson \& Swan, 2003; Moisey, Neu, \& Cleveland-Innes, 2008), and enhanced learning achievement (LaPadula, 2003; Overbaugh \& Lin, 2006). Rovai (2001) found a significant relationship between classroom communities, the flow of information among online learners, and effective learning.

Technology, social interactions, and the learning content are crucial components of an effective learning community. According to Carabajal, Lapointe, and Gunawardena (2003), there are three dimensions of an online community: a technological dimension, a task dimension, and a social dimension. Carabajal et al. argue that the technology has important consequences for the successful accomplishment of group tasks and the successful maintenance of the group. The technology, Carabajal et al. explain, must allow group members to contribute knowledge; provide scaffolded assistance and the interaction tools needed to adequately relate concepts, experience, and knowledge; and provide a space for the group's memory. The task dimension includes the learning content, materials, resources, and activities used in the courses (Carabajal et al., 2003). Carabajal et al. state that the social dimension refers to participants maintaining some degree of mutual caring and understanding through frequent interaction. Tu and Corry (2002) propose a similar theoretical framework that includes instruction, social interaction and technology as the three major dimensions of their e-learning community.

Interaction is an essential element of the development of the sense of community. Moore (1989) distinguishes three types of interaction: learner-content, learner-instructor and learner-learner. Moore defines learner-content interactions as "the process of intellectually interacting with content that results in changes in the learner's understanding, the learner's perspective, or the cognitive structures of the learner's mind" (p. 2). According to Moore, learner-instructor interactions establish an environment that encourages learners to understand the content better. This type of interaction is "regarded as essential by many educators and highly desirable by many learners" (p. 2). Moore explains that learner-learner interactions take place "between one learner and other learners, alone or in group settings, with or without the real-time presence of an instructor" (p. 4). Several studies support the importance of interactions and learning as essential elements of a cohesive learning community. Fredericksen, Pickett, Shea, Pelz, and Swan (2000) surveyed 1,406 students enrolled in online university courses. They found that students who reported the highest levels of perceived learning also reported the highest levels of interaction with the instructor, higher levels of interaction with classmates, and more participation in their online classes than in their face-to-face classes. Wang (2005) found that social interaction in an online learning community 
Web 2.0 Technologies and Building Online Learning Communities: Students’ Perspectives

facilitated learning by contributing to the sense of community, reducing feelings of isolation and providing a context for appreciating diverse perspectives.

\section{Social Presence}

There is a strong connection between the development of a sense of social presence and the formation of online communities (Palloff \& Pratt, 2007; Garrison, Anderson \& Archer, 2000). Garrison et al. (2000) believe that in order to form a community online, a sense of social presence is required among participants. Garrison et al. define social presence as "the ability of participants in the community of inquiry to project their personal characteristics into the community, thereby presenting themselves to others as 'real people’” (p. 94). Recently, Kreijns, Kirschner, Jochems, and Buuren (2011) defined social presence as "the degree of illusion that others appear to be a 'real' physical person in either an immediate (i.e., real time/synchronous) or a delayed (i.e., time-deferred/asynchronous) communication episode” (p. 365).

Social presence is critically important to the success of online courses and to the quality of the online learning experience. Social presence has been correlated with learner satisfaction online (Tu, 2001; Kreijns et al., 2011) and to a sense of belonging to a community (Picciano, 2002). Social presence also influences student learning (Richardson \& Swan, 2003; Swan \& Shea, 2005). Additionally, social presence is an important determinant for social interaction (Cobb, 2009; Garrison, Anderson, \& Archer, 2003; Lowenthal, 2010; Swan, 2002). According to Palloff and Pratt (2007), when there is a high degree of social presence, the degree of interaction between the participants is also high. Picciano (2002) found that perceptions of social presence were correlated with perceptions of learning and interaction, and that perceived learning and perceived interactions were also correlated. Picciano cautions, however, that interaction and presence are not one and the same: "Interaction may indicate presence but it is also possible for a student to interact by posting a message . . . while not necessarily feeling that she or he is part of a group or a class” (p. 22). Simply getting students to talk to one another is not sufficient. Educators need to develop authentic and effective ways to assist students in connecting with peers and building relationships.

Garrison et al. (2000) suggest three categories contributing to the development of social presence among students: emotional expression, open communication, and group cohesion. According to Garrison et al., emotional expression is indicated by the ability and confidence to express feelings related to the educational experience. Self-disclosure is an example of emotional expression and is described as a sharing of feelings, attitudes, experiences, and interests (Garrison et al., 2000). The second category of indicators of social presence is open communication. Garrison et al. argue that responses and rejoinders to the comments and contributions of others are examples of open communication. Thus, using the reply feature to post messages, directing a comment to someone in particular, and referring explicitly to the content of others' messages can contribute to the development of students' sense of social presence. The third category of social presence indicators is group cohesion. This category is exemplified by activities that build and sustain a sense of group commitment (Garrison et al., 2000). For helping students to work effectively in activities that involve online collaboration and reduce resistance to the activity, Palloff and Pratt (2007) suggest providing students with an explanation of the importance of and reasons for including collaborative activities. Dell (2004) stresses the importance of giving clear instructions and guidelines regarding not only the assignments but also the method and tools of communication that will be used. Dell also suggests designing evaluation criteria to include peer evaluation. He argues that peer evaluation rewards extraordinary team members while appropriately evaluating noncontributing members. Additionally, the use of an agreement or contract among group members has been noted to be significant in promoting learner satisfaction with collaborative learning experiences online (Murphy et al., 2000; Doran, 2001).

\section{Web 2.0 Technologies}

When students participate in online courses the communication that is needed to create and maintain social interaction usually requires technological mediation (Kearns \& Frey, 2010). Web 2.0 
Web 2.0 Technologies and Building Online Learning Communities: Students’ Perspectives

technologies can effect that mediation. The term Web 2.0 was first used in 2004 and referred to the second generation of the Internet (Schrum \& Levin, 2009). The main characteristics of Web 2.0 technologies, as Schrum and Levin (2009) explain: are that they allow users to add and change content easily, collaborate and communicate instantaneously in order to share, develop and distribute information. Web 2.0 technologies can play an important role in the development of a learning community among students in online courses (Kearns \& Frey, 2010; Palloff \& Pratt, 2009; Gunawardena et al., 2009). According to Palloff and Pratt (2009), Web 2.0 technologies have the ability to enhance the development of learning communities and reduce the isolation and distance felt by students in online courses. Kearns and Frey (2010) recommend that faculty interested in developing communities among their online students need to learn about and experiment with a variety of Web 2.0 technologies in order to make students aware of their potential for back-channel communication. Web 2.0 tools range from those that allow for personal expression to those that support community building (Palloff \& Pratt, 2009). Some of the common forms of Web 2.0 technologies currently being integrated into online courses include Skype, Twitter, Google Docs, blogs, and wikis.

Skype is an Internet-based phone service that also allows for conference calling, document sharing, and text messaging (Palloff \& Pratt, 2009). Parker, Boase-Jelinek, and Herrington (2011) found Skype to be a good tool for building rapport and social presence among online students. Parker et al. (2011) explain that Skype gave students the opportunity to chat with their peers about how they were progressing in the unit and to share resources, problems and solutions with each other. They also found that Skype allowed the instructor to provide immediate responses to student questions that everyone could see and to chat with a number of students at the same time. Parra (2013) found that Skype was one of the most beneficial and valued online collaborative work tools.

Twitter is a form of a social networking space that allows for microblog entries known as "tweets" (Schrum \& Levin, 2009). In 140 characters or fewer, people share ideas and resources, ask and answer questions, and collaborate on problems of practice. Twitter community members post their contributions via the Twitter website, mobile phone, e-mail, and instant messaging-features make Twitter a powerful, convenient microsharing environment (Drapeau, 2009). All of this communication happens in real time, so the exchange of information is immediate (Dunlap \& Lowenthal, 2009). Depending on whom one chooses to follow, Twitter can be effectively used for professional and social networking because it can connect people who have similar interests (Lucky, 2009). Twitter can also be an effective way to enhance online learning communities (Dunlap \& Lowenthal, 2009). Dunlap and Lowenthal found Twitter to be a powerful tool for establishing informal, free-flowing, just-in-time communication between and among students and faculty, and with the professional community at large.

Google Docs is a free web-based application that allows users to create word processing documents. The Google Doc application allows access to a document from any computer and enhances collaboration by providing a way to share that document with others as viewers or collaborators, or by publishing it on the web (Conner, 2008). Reyna (2010) argues that Google Docs can be an excellent resource for overcoming students' sense of isolation. Google Docs can support collaborative writing among students (Brodahl, Hadjerrouit, \& Hansen, 2011; Blau \& Caspi, 2009). Parra (2013) found that the Google Doc application was one of the most beneficial and valued online collaborative group-work tools. Google Docs enable users to edit a document written by other students and suggest modifications by writing comments rather than editing the document itself-features that afford real-time collaborative learning.

A blog is a frequently updated online diary or journal; it can be used for news, reviews, personal thoughts, experiences, web links and photos (Schrum \& Levin, 2009). Via blogs, students enjoy an opportunity to open the windows of communication by reading their classmates' postings and having classmates comment on their own writing (Windham, 2007). Clake and Kinne (2012) found that students who used blogs felt a great sense of satisfaction and engagement with the community as a result of using the blogs. In Clake and Kinne's study, the students found that blogs released them from the typical 
Web 2.0 Technologies and Building Online Learning Communities: Students’ Perspectives

participation structures found in classroom discussions and allowed them to broaden the way they converse with others in an online class setting.

A wiki is a collection of web pages designed to enable anyone who accesses it to contribute and/or modify content (Dunlap \& Lowenthal, 2009). Wikis allow people to directly update, modify, or delete content and allow multiple users from different locations to collaborate in real time. A wiki is also an effective technology for building learning communities (Lambert \& Fisher, 2009; Scott \& Liu, 2011). Lambert and Fisher (2009) argue that a wiki offers benefits not typically found in traditional content management systems, such as interaction, creativity, virtual collaboration, resource sharing, joint authorship, seamless integration of Internet-based content, and ease of use. These benefits provide a medium that can be more conducive to building online communities.

\section{Purpose of the Research}

Given the apparent ability of Web 2.0 technologies to enhance the development of learning communities and reduce the isolation and distance felt by students in online courses, we raised the following question: What are students' perspectives on using Web 2.0 technologies to develop a community of learners?

\section{Methodology}

\section{Action Research}

I chose action research as my research methodology. According to Parsons and Brown (2002), to be an effective educator one must be an "active participant" in the classroom, observing, analyzing, and interpreting information about student learning and then using this information for planning and decision making (p. 22). Carr and Kemmis (1986) define action research as "simply a form of self-reflective inquiry undertaken by participants in social situations in order to improve the rationality and justice of their own practices, their understanding of these practices, and the situations in which the practices are carried out” (p. 162). The basic elements of an action research model are cycles of planning, acting and observing, and reflecting (Lewin, 1948). In an action research project, planning, data collection, data analysis, and the production of results are continuous throughout its cyclical process. After the planning phase, data is collected during the acting and observing phase, and that data is analyzed during the reflecting phase to inform the next planning phase of the next cycle of action research (Lewin, 1948).

In the current study, the planning phase included identifying suitable Web 2.0 technologies that were freely available. A review of the literature on building online learning communities was conducted. Assignments and activities for using Skype, Twitter, Google Docs, wikis and blogs were created with basic instructional scaffolding as described in the following section. During each cycle's acting and observing phase, the action was implemented, and data was collected. The development of learning communities was informally monitored through students' interactions with each other, the content and the instructor. Reflecting is the main focus of the third phase of each action research cycle. During this phase, results are evaluated and outcomes are reflected upon. The data were analyzed for patterns and insights.

\section{Web 2.0 Technologies in Action}

The course described in this study was a fully online course of 25 students in an Educational Learning Technologies master's program at a medium-sized university in the U.S. Southwest. This course focused on technology and pedagogy. The course content was organized into five modules on Canvas. A variety of Web 2.0 tools (Twitter, Google Docs, Skype, blogs, and wikis) was used throughout the course modules to enhance students' sense of community. In the first module, students were tasked to create a Skype account, a Gmail account, and a Twitter account and to send the instructor a message using these tools (see Appendix A). The purpose was to help students become familiar with these tools before they used them during the semester.

Skype was used to support student-instructor and student-student interactions. Skype was on the instructor's desktop; students could send the instructor a text chat message if they saw her online in Skype. 
Web 2.0 Technologies and Building Online Learning Communities: Students’ Perspectives

If not, they could type their questions, and the instructor would answer as soon as she got back. Students also were advised to use Skype to communicate with their groups in order to complete the group work.

Twitter was used to facilitate class discussions about the week's topic. The purpose was to enhance student-content interactions and student-student interactions. The students were asked to read the required articles about the week's topic and tweet about what they learned from the week's readings using the course hashtag "\#EDUC518." Students were also required to reply to at least two of their classmates' tweets. Students' tweets were graded based on a rubric.

In another module, students were tasked to create a Google Doc describing one learning activity for using a self-selected technology tool in their own teaching. Students were asked to share their Google Docs with their classmates and the instructor. Students were required to comment on each other's activities by directly writing in their classmates' Google Docs. Students were also advised to use Google Docs to communicate with their groups.

Blogs were used in order to facilitate students' interactions with the content and with each other. Students were required to create blogs using Blogger or any other blogging site and to engage in conversations through these blogs (see Appendix B). The students were to blog in response to a prompt. Then they were required to read and comment on each other's blogs. The course assigned three blogs. Rubrics were used to grade students' blogs and their feedback to each other.

The students were tasked to work in groups of three or four and collaboratively complete the wiki project. Students were asked to create their groups two weeks before the start of the collaborative activity in order to give them enough time to select team members. Additionally, students were provided with a written explanation of the importance of the collaborative work as well as instructions for completing it (see Appendix C). Students were also given guidance on establishing group policies and procedures and suggestions regarding collaborative technology tools they could use (see Appendix D). Before beginning the group activity, the students were required to complete the group-contact template suggested by Conrad and Donaldson (2004) (see Appendix E). This document suggests that group members specify the primary method and frequency of communication, make contingency plans for emergencies, and decide whether to select a group leader.

In the last module the students were tasked to collaboratively write a wiki about the module's topic (see Appendix F). Each group's wiki was required to contain five pages and follow a specific format provided by the instructor. One of the group members would need to volunteer to create a wiki using PBworks or any other wiki site and invite his or her classmates to the wiki he or she created. Students as groups would need to collaborate with each other to create the first two pages of the wiki following the instructions provided by the instructor. Then students were individually responsible for creating a page within the group's wiki about a topic of their interest. Additionally, students were required to individually do a peer review of at least two of their classmates' wikis by directly commenting in them. The wiki project was graded based on (a) the quality of the content using a rubric and (b) peer evaluation in which students were asked to assess each other's performance in the collaborative project using a rubric.

\section{Data Collection}

The methods of data collection in this study included students' reflective journaling activities, researchers' journal and field notes, and students' comments on each other's reflections. At the end of each module, students were asked to reflect on whether the Web 2.0 tool they used in the module gave them a sense of a learning community and why the tool gave them this sense of community (or why it did not). The course assigned five reflective journaling activities (one reflective activity for each Web 2.0 tool used in the course). The students were also asked to share their reflections in the Canvas discussion forum and comment on each other's reflections. The students were given the following reflective writing prompt: "Did using Google Docs give you a sense of a learning community? Why or why not? Did using Skype give you a sense of a learning community? Why or why not? Did using Twitter give you a sense of a learning community? Why or why not? Did using a blog give you a sense of a learning community? Why or why not? Did the wiki project give you a sense of a learning community? Why or why not?” (See 
Web 2.0 Technologies and Building Online Learning Communities: Students’ Perspectives

Appendix G for an example reflective activity.) Additionally, the instructor kept an ongoing record of her reflections on what she was observing (why she thought things were the way they appeared) and any interactions she experienced, with the goal of building understanding. Data collection through this method was used to substantiate data collected from students’ reflective journaling activities.

\section{The Participants}

The 25 graduate students included nine Caucasian females, two Caucasian males, eight MexicanAmerican females, five Mexican-American males, and one African-American male. Their ages ranged from 23 to 40 years; 12 participants were in their twenties, nine were in their thirties, and four were in their forties. This course represented the first online class for $75 \%$ of the learners.

\section{Limitations}

This study is limited by the methodology and the researcher's role in the course. This study focused on one instructor in a single online course, and the instructor is also the researcher. The findings from this study, therefore, have limited generalizability.

\section{Data Analysis}

Data collected from the journals and students' comments on each other's reflections were read carefully by underlining words, phrases, sentences, or paragraphs that struck the researcher as important insights related to the focus of this research. This process was repeated several times to show the levels of felt significance, as Saldana (2012) recommends. During these processes of reading and rereading, the researcher began to identify the emerging categories. As themes emerged, the data within each theme was compared. The themes were named using words from the students' data, and rich descriptions including quotes directly from the participants were used to fully illustrate each category’s meaning.

\section{Findings}

\section{Students' Perspectives}

Students indicated that using Google Docs, wikis, blogs, and Twitter gave them a sense of a learning community while using Skype did not give them this sense of community. Google Documents and wikis had the greatest impact on students' sense of a learning community in the course. The following section summarizes students' perspectives on using Google Docs, wikis, blogs, Twitter, and Skype to develop learning communities.

\section{Google Docs}

The majority of the students agreed that using Google Docs gave them a sense of a learning community. The students expressed that using Google Docs was a great way to collaborate. They explained that Google Documents allowed all members to collaboratively work on the document while separate from each other. This capacity for collaboration made the group project easy to complete and gave them a sense of a learning community in the course. The following are students' own words about their experiences:

- "Google Doc was a great way for collaboration. All members of the group were able to collaborate simultaneously. I loved how each member could work on the single document at the same time. This makes group projects so much easier to complete.”

- "Using Google doc to communicate with my group gave me a sense of a learning community. We were able to work together while being apart. This made collaboration possible; we did not have to take time out of our lives to meet in person somewhere but work at times that were convenient for us.”

- "Google drive is definitely on my top list. I did use Google doc to communicate with my group. It made it felt like we were sitting in class together working on the same paper, but on my own time."

Some students perceived the Google Doc application as a great tool for building a learning community 
Web 2.0 Technologies and Building Online Learning Communities: Students’ Perspectives

through the open exchange of ideas and information. These students stated the following:

- "Google doc lets me share information with my classmates no matter where they were and what they were doing. We really come together as a learning community. Google doc is the best way to create learning communities.”

- "Google doc was one of the primary ways the groups I worked with communicated and collaborated. This technology provided a great sense of learning community through the ways we used the Google Doc as an open forum. One group member could pose an idea or question and the rest of the group could add, edit or comment on the idea."

Some other students expressed the feeling that Google Docs gave them a sense of a learning community by providing the ability to edit documents written by other students and the ability to suggest improvements by writing comments:

- "Google Doc has been my favorite part of this class. Google doc allowed for several students to edit a project they can all have access and view from anywhere. It saves paper it saves doing time that I am not doing something many times and if there was a mistake I can correct it and highlight it and I know what I need to change next time. I believe using Google Doc to communicate with my group did give me a sense of learning community. It was awesome actually.”

- "Google Drive was by far one of the best things I was introduced to in the course. The ability to work on a project or any other type of document with others in real time from anywhere was great. We could edit and communicate. Before Google drive, students had to email files and combined feedback from multiple students into one file. Google drive truly gave me a sense of learning community."

- "It allowed for not only my groups to communicate with each others but it too allowed my classmates and instructor to communicate with me and I with them, and give and receive feedback in real time. Being able to read their comments and get their feedback allowed me to evaluate my work and improve it. This is how Google doc gave me a sense to what a learning community is.”

\section{The Wiki Project}

The majority of students strongly agreed that the Wiki Project gave them a sense of a learning community. Some students expressed the opinion that the wiki project enabled them to learn from each other through the ability to share ideas and information with other students, which created a true learning community. These students stated the following:

- "Working with my Wiki group was a great example of a learning community. We all contributed with ideas and all learned from the strengths of each other. When one person was particularly good at a task we would all learn from him and when another person was creative in visual design we would all learn from his strength. Overall I felt that the final outcome of our Wiki project was the combination of all of our group members' strengths."

- "Working in groups in the Wiki project gave me a sense of a positive learning community. The wiki project provided a better opportunity for a learning sharing community. When there are more than two people, more ideas are definitely brought up."

- "I really enjoyed this assignment in full. Being able to work with a group and to collaboratively write a wiki truly gave me a sense of a learning community. This was done by being able to work with other and share information and ideas. The constant interaction and sharing gave me a real sense of a learning community."

Some students expressed the feeling that the exchange of comments within the wiki gave them a sense of a learning community. However, other students explained that the commenting feature in the PBworks was an obstacle to their sense of community: 
Web 2.0 Technologies and Building Online Learning Communities: Students’ Perspectives

- "Working in a group for the wiki project definitely provided a sense of a learning community, especially when we had to review the other group's wikis to provide feedback and critique. The assignment was planned well and allowed for collaboration between group members and pushed the class to evaluate each other's work in a constructive manner."

- "The commenting feature on the wiki was a bit more tedious to work through because people who wanted to comment had to be added before they could do so. Since the wiki was limited to just a selected few in the class it didn't give me the same sense of community as some of the other activities."

Some students explained that using the group contact was a major factor affecting the effective use of the wiki:

- "Creating a contract was such a great foundation for our project, and it was something we could always turn to when in doubts for our responsibilities and what we were trying to get across in our wiki.

- "The group contract made me feel that I was liable for doing this actual assignment and owned responsibility for my parts in the assignment."

- "The use of contract among group members facilitated collaborative learning experiences. By creating a group contract we each were held responsible for the contribution and success of the group work.”

\section{Blogs}

The students agreed that using blogs gave them a sense of a learning community. Some students expressed the opinion that the commenting feature in the blogs allowed them to actively engage with one another's ideas and perspectives:

- "The commenting feature in the blog was very easy to use, and I enjoyed the feedback directly on my blog, which gave me a sense of a learning community."

- "Commenting on blogs was like social media. I have never read a blog or write in a blog, but while doing it I realized that it was just like MySpace or Face Book. The learning community was strong and made me realize I have been doing that for my own pleasure, not for academia."

- "The commenting feature on blog definitely made it easy to communicate because I get emails right away that someone commented on my blog. That is really neat because you are able to provide feedback to one another really quickly and being an online course that is really important communication."

Some students expressed the feeling that receiving feedback about their work from their classmates supported their sense of a learning community:

- "Being able to receive feedback on one’s blog is excellent. To receive advice and exchange ideas is an excellent feature that I used in communicating with my classmates. Any times comment that can be used to better improve one's blog is a huge plus. This is a perfect source of communication with classmates and is a perfect example of a learning community."

- "I do think that the feedback created a learning community. Receiving feedback felt like my classmates cared about my project; they actually read what I had to say and gave great input."

Other students explained that being able to see their classmates' work and how they dealt with the week's topic or assignment had a positive impact on their sense of community:

- "The blogs we created were an excellent way to promote a learning community. By far they were the most comprehensive in displaying students work and fostering meaningful feedback/critique. There is a definite value in utilizing this tool for learning sharing. If I ever had questions regarding an assignment it was always nice to see the different solutions my classmates arrive at when approaching similar obstacles." 
Web 2.0 Technologies and Building Online Learning Communities: Students’ Perspectives

\section{Twitter}

The students expressed the opinion that using Twitter gave them a sense of a learning community. Some students perceived Twitter to be a good tool for building a learning community because it enabled them to share their own ideas and to read others' ideas. The following are some examples of comments made by students:

- "Using Twitter gave me a sense of a learning community. Sharing Tweets and reading Tweets of other made me feel connected to a learning community."

- "Twitter allowed for students to be able to post ideas, read other's ideas, and comment on other's ideas. This gave me a sense of community by being able to share ideas."

Some students used Twitter not only to communicate with their classmates but also to connect with others who shared similar interests, which gave them a "great" sense of a learning community, as mentioned by this student:

- $\quad$ "By setting up a Twitter account I was able to get to know others not only in our course but others in the same field as well. This gave a great sense of a learning community. Now I have 'friends' that are in the same field as I am and I get to see and hear about their experiences and crafts that they use in their own classrooms."

Some students expressed that using the hashtag feature in Twitter supported their sense of community:

- "Before this class, I used twitter to read news. During this class, I learned about the ability to create learning communities using the hashtags. With the hashtags, we are able to share links to resources and tweet /discuss topics with other students.”

Some students perceived Twitter to be a good tool for building a learning community because of the ease of using the Twitter application in their cell phones:

- "Using Twitter gave me a sense of a learning community. It is really easy to use. You can even use it on your cell phone. Sharing Tweets and reading tweets of other on my cell phone made me feel connected to a learning community."

Other students, however, felt that using Twitter did not give them a sense of a learning community because the use of Twitter was limited to only one assignment. Other students expressed the opinion that they preferred to use Twitter for personal purposes and that they were not comfortable using it in the class:

- $\quad$ "For Twitter, I didn't really feel the sense of learning community. It probably can be a useful tool but with Canvas and other Web 2.0 tools we used over the duration of the course I found it unnecessary. Perhaps if we used it more in more than one assignment, it could be a useful collaborative tool."

- "Twitter did not give me a sense of a learning community because I have had a Twitter account for many years and use it for my personal entertainment. I did not feel comfortable using Twitter for this class, I had to make a new account just for class and I never logged on again to that account after our assignment was done.”

\section{Skype}

Few students felt that Skype gave them a sense of a learning community. The majority of the students did not use Skype to communicate with their groups. Instead, they used their cell phones or the messaging feature in Canvas to communicate with their peers:

- "I did not use Skype to communicate with my group. We did not feel that we needed to use it. We exchanged not only email addresses, but also cell phone numbers in order to be able to contact one another when needed."

- "I did not use Skype to communicate with my group; we had a lot of scheduling issues. Along with the wiki project, we used Google doc and Canvas messaging to work out our schedules duties and addressing our questions.” 
Web 2.0 Technologies and Building Online Learning Communities: Students’ Perspectives

On the other hand, some students saw Skype as a good tool to communicate with their group members because it was similar to face-to-face communication. Other students indicated the Skype chat gave them easy access to the instructor:

- "Using Skype to communicate with our group gave me a sense of community. It was a great tool to have a conversation 'face to face."”

- "Skype is an excellent tool that allows anyone to communicate online face to face. It is perfect for the sharing of ideas especially in group projects."

- "I never really got the chance to use Skype to communicate with my group. However Skype was a great tool for communicating with the instructor. When I could not find solutions from my classmates her availability made possible for me to navigate parts of the course that I found difficult or misunderstood.”

- "I did not use Skype to communicate with my group. However, I did use it to communicate with my instructor and her responses were fast and easy because it seemed very direct."

\section{Discussion and Implications}

The goal of this action research was to explore students' perspectives on using Web 2.0 technologies to develop a community of learners. The students perceived Google Docs to be a good tool for building a learning community. They expressed the opinion that Google Docs facilitated collaboration by providing students with the ability to edit documents written by other students from anywhere and at any time, to share ideas and information, and to suggest improvements by writing comments. Based upon this finding, the author will strongly consider using Google Docs as a way to support and facilitate collaborative group work.

The students also said that the Wiki Project gave them a sense of a learning community by providing them with the ability to learn from each other, to share ideas and information, and to exchange comments; however, some students struggled with the commenting feature in PBworks and felt it was an obstacle to the creation of a sense of a learning community. Only users appearing in the users list of a workspace would be able to make comments. Anonymous users or users who were logged in with a PBworks account but who had not joined the group space could not make any comments on any page. This limitation would require students to add everyone in the class to the username list whether they had a PBworks account or not, which would be difficult in a class of 25 students. In order to solve this problem and to enable students to comment on each other's wikis, the instructor created a peer review schedule in which two groups were assigned to review each group's wiki. Even with this solution, students struggled to understand the process and considered it to be complicated, especially when the groups whose wikis were required to be reviewed were different than the groups whose wikis were required to be added to, which made it difficult to follow up on the process. Based on this experience with PBworks, the author will create a class wiki to which all students are added; then each group can be responsible for creating a page in the class wiki. As a result of the author taking this approach, all students will be able to comment on each group's work.

The author will continue use the group contact to promote learner satisfaction with collaborative learning experiences online because students explained that the group contact was a major factor that made wiki use effective.

Findings also revealed that using blogs and Twitter gave students a sense of a learning community. The students said that using the blogs' commenting feature gave them a sense of community, enabling them to receive feedback about their work from their classmates and to see their classmates' work. The students felt that using Twitter gave them a sense of a learning community by providing them with the ability to share ideas not only with their classmates but also with others who had similar interests. Using the hashtag feature in Twitter and using the Twitter cell phone application also supported students' sense of community; however, some students said that using Twitter did not give them a sense of a learning community because the use of Twitter was limited to one assignment or because they preferred 
Web 2.0 Technologies and Building Online Learning Communities: Students’ Perspectives

to use Twitter for personal purposes. Despite the misgivings of these students, the author will nonetheless extensively use Twitter and blogs throughout future courses to help students experience how these tools can be used for educational purposes since so many students found them useful in this study.

Few students said that Skype gave them a sense of a learning community. The majority of the students did not use Skype to communicate with their groups; rather, they preferred using their cell phones or the messaging feature in Canvas. Therefore, the use of Skype will be modified; the author will ask students to schedule Skype sessions with her to discuss students' progress in the course activities. The purpose is to help students to experience the power of Skype to facilitate communication among the students and between students and the instructor.

In sum, building and sustaining strong learning communities should be an essential dynamic in virtual classrooms. The findings from the current study suggest that Web 2.0 technologies can promote students' sense of learning communities in online classes. It is true that building online learning communities is a difficult task; however, doing so is an integral step for improving learning and teaching in online environments, and thus work in this area should continue.

\section{References}

Buckingham, S. (2003). Perspectives on the experience of the learning community through online discussions. Journal of Distance Education, 18(2), 74-91.

Blau, I., \& Caspi, A. (2009). What type of collaboration helps? Psychological ownership, perceived learning and outcome quality of collaboration using Google docs. Proceedings of the Chais Conference on Instructional Technologies Research: Learning in the Technological Era. In Y. Eshet-Alkalai, A. Caspi, S. Eden, N. Geri, \& Y. Yair (Eds.), Raanana: The Open University of Israel.

Bonk, C., \& Wisher, R. (2000). Applying collaborative and e-learning tools to military distance learning: A research framework. United States Army Research Institute for the Behavioral and Social Sciences.

Brodahl, C., Hadjerrouit, S., \& Hansen, N. (2011). Collaborative writing with Web 2.0 technologies: Education students' perceptions. Journal of Information Technology Education: Innovations in Practice, 10, 73-103.

Brook, C., \& Oliver, R. (2003). Online learning communities: Investigating a design framework. Australian Journal of Educational Technology, 19(2), 139-160. Retrieved fromhttp://www.ascilite.org.au/ajet/ajet19/brook.html

Carabajal, K., LaPointe, D., \& Gunawardena, C. (2003). Group development in online learning communities. In M. Moore \& W. Anderson (Eds.). Handbook of distance education ～(pp. 217-244). London: Lawrence Erlbaum Associates.

Carr, W., \& Kemmis, S. (1986). Becoming critical: Education, knowledge and action research. Berlin: Falmer Press.

Clake, L., \& Kinne, L. (2003). More than words: Investigating the format of asynchronous discussions as threaded discussions or blogs. Journal of Digital Learning in Teacher $\quad$ Education, 29(1), 4-13.

Cobb, S. (2009). Social presence and online learning: A current view from a research perspective. Journal of Interactive Online Learning, 8(3), 241-254.

Conner, N. (2008). Google apps: The missing manual. Sebastopol, CA: O’Reilly Media.

Conrad, R., \& Donaldson, A. (2004). Engaging the online learners: Activities and resources for creative instruction. San Francisco, CA: Jossey-Bass.

Dell, D. (2004). Philosophy of online teaching. Capella University. Retrieved from 
Web 2.0 Technologies and Building Online Learning Communities: Students’ Perspectives

http://dianadell.com/eportfolio/philosophy.html

Dixon, J., Crooks, H., \& Henry, K. (2006). Breaking the ice: Supporting collaboration and the development of community online. Canadian Journal of Learning and Technology, 32(2), 1-14.

Doran, C. (2001). The effective use of learning groups in online education. New Horizons in Adult Education, 15(2). Retrieved from http://www.nova.edu/ aed/horizons/volume15n2.html

Drapeau, M. (2009). What is Twitter's vision? Retrieved from http://mashable.com/2009/02/02/what-istwitters-vision/

Dunlap, J., \& Lowenthal, P. (2009). Tweeting the night away: Using Twitter to enhance social presence. Journal of Information Systems Education, 20(2), 129-135.

Fredericksen, E., Pickett, A., Shea, P., Pelz, W., \& Swan, K. (2000). Student satisfaction and perceived learning with online courses: Principles and examples from the SUNY learning network. Journal of Asynchronous Learning Networks, 4(2), 7-41.

Garrison, R., Anderson, T., \& Archer, W. (2000). Critical inquiry in a text-based environment: Computer conferencing in higher education. The Internet and Higher Education, 2(2-3), 87-105.

Garrison, R., Anderson, T., \& Archer, W. (2003). Theory of critical inquiry in online distance education. In M. Moore \& W. Anderson (Eds.). Handbook of distance education (113-128). London: Lawrence Erlbaum Associates.

Gunawardena, C., Hermans, M., Sanchez, D., Richmond, C., Bohley, M., \& Tuttle, R. (2009). A theoretical framework for building online communities of practice with social networking tools. Educational Media International, 46(1), 3-16.

Hiltz, S. R. (1998). Collaborative learning in asynchronous learning environments: Building learning communities. The WebNet 98 World Conference of the WWW, Internet and Intranet Proceedings, Orlando, Florida.

Kearns, L., \& Frey, B. (2010). Web 2.0 technologies and back channel communication in an online learning community. TechTrends, 54(4), 41-51.

Kreijns, K., Kirschner, P. A., Jochems, W., \& van Buuren, H. (2011). Measuring perceived social presence in distributed learning groups. Education and Information Technologies, $\quad$ 16(4), 365-381.

Lambert, J., \& Fisher, J. (2009). Community building in a Wiki-based distance education course. In G. Siemens \& C. Fulford (Eds.), Proceedings of World Conference on Educational Multimedia, Hypermedia and Telecommunications (1527-1531). Chesapeake, VA: AACE.

LaPadula, M. (2003). A comprehensive look at online student support services for distance learners. The American Journal of Distance Education, 17(2), 119-128.

Lewin, K. (1948). Resolving social conflicts: Selected papers on group dynamics. New York: Harper \& Row.

Lowenthal, P. R. (2010). The evolution and influence of social presence theory on online learning. In T. Kidd (Ed.), Online education and adult learning: New frontiers for teaching practices (124-134). Hershey, PA: IGI Global.

Lucky, R. (2009). To Twitter or not to Twitter? IEEE Spectrum, 46(1), 22-23.

McMillan, D. W., \& Chavis, D. M. (1986). Sense of community: A definition and theory. Journal of Community Psychology, 14(1), 6-23. 
Web 2.0 Technologies and Building Online Learning Communities: Students’ Perspectives

Moisey, S., Neu, C., \& Cleveland-Innes, M. (2008). Community building and computer- mediated conferencing. Journal of Distance Education, 22(2), 15-42.

Moore, M. (1989). Three types of interaction. The American Journal of Distance Education, 3(2), 1-6.

Murphy, K., Mahoney, S., \& Harvell, T. (2000). Role of contracts in enhancing community building in Web courses. Educational Technology \& Society, 3(3), 409-421.

Overbaugh, R., \& Lin, S. (2006). Student characteristics, sense of community, and cognitive achievement in Web-based and lab-based learning environments. Journal of Research on Technology in Education, 39(2), 205-223.

Palloff, R., \& Pratt, K. (2007). Building online learning communities: Effective strategies for the virtual classroom. San Francisco: Jossey-Bass.

Palloff, R., \& Pratt, K. (2009). Web 2.0 technologies and community building online. Proceedings of the 25th Annual Conference on Distance Teaching and Learning.

Parker, J., Boase-Jelinek, D., \& Herrington, J. (2011). Perceptions and reflections: Using Skype chat to build a community of learners. Proceedings of World Conference on E-Learning in Corporate, Government, Healthcare, and Higher Education (pp. 1599-1604). Chesapeake, VA: AACE.

Parra, J. (2013). Developing technology and collaborative group work skills: Supporting student and group success in online and blended courses. In C. Wankel \& P. Blessinger (Eds.), Cutting-edge technologies in higher education: Vol. 6. Increasing student engagement and retention in elearning environments: Web 2.0 and blended learning technologies (pp. 287-337). Emerald Group Publishing Limited.

Parsons, R. D., \& Brown, K. S. (2002). Teacher as reflective practitioner and action researcher. Belmont, CA: Wadsworth/Thomson Learning.

Picciano, A. (2002). Beyond student perceptions: Issues of interaction, presence, and performance in an online course. Journal of Asynchronous Learning Networks, 6(1), 21-40.

Reyna, J. (2010). Google Docs in higher education settings: A preliminary report. Proceedings of World Conference on Educational Multimedia, Hypermedia and Telecommunications （pp. 15661572). Chesapeake, VA: AACE.

Richardson, J., \& Swan, K. (2003). Examining social presence in online courses in relation to students' perceived learning and satisfaction. Journal of Asynchronous Learning Networks, 7(1), 68-88.

Rovai, A. P. (2001). Building classroom community at a distance: A case study. Educational Technology Research and Development, 49(4), 33-48.

Rovai, A. (2002). Building sense of community at distance. The International Review of Research in Open and Distance Learning, 3(1). Retrieved from http://www.irrodl.org/index.php/irrodl/article/view/79/152

Russell, M. (1999). Online learning communities: Implications for adult learning. Adult Learning, 10(4), 28-31.

Saldana, J. (2012). The coding manual for qualitative researchers (2nd ed.). Thousand Oaks, CA: Sage Publications Ltd.

Schrum, L., \& Levin, B. (2009). Leading 21st century schools. Thousand Oaks, CA: Corwin.

Scott, C., \& Liu, Y. (2011). Using Wiki tools to promote community learning. In M. Koehler \& P. Mishra (Eds.), Proceedings of Society for Information Technology \& Teacher Education International Conference (1671-1674). Chesapeake, VA: AACE. 
Web 2.0 Technologies and Building Online Learning Communities: Students’ Perspectives

Swan, K. (2002). Building learning communities in online courses: The importance of interaction. Education, Communication and Information, 2(1), 23-50.

Swan, K., \& Shea, P. (2005). The development of virtual learning communities. In. S. Hiltz \& R. Goldman. Asynchronous learning networks: The research frontier (pp. 239-260). New York: Hampton Press.

Tu, C. (2001). How Chinese perceive social presence: An examination of interaction in an online learning environment. Educational Media International, 38(1), 45-60.

Tu, C., \& Corry, M. (2002). eLearning communities. The Quarterly Review of Distance Education, 3(2), 207-218.

Wang, H. (2005). A qualitative exploration of the social interaction in an online learning community. International Journal of Technology in Teaching and Learning, 1(2), 79-88.

Wiesenfeld, E. (1996). The concept of “we”: A community social psychology myth? The Journal_of Community Psychology, 24(4), 337-346.

Windham, C. (2007). Reflecting, writing, and responding: Reasons student blog. Retrieved from https://net.educause.edu/ir/library/pdf/eli8006c.pdf

\section{Appendix A}

\section{Setting Up Your Course Tech Toolkit}

Setting Up Your Course Tech Toolkit. Time: 15 min.-2 hours. Value: 15 points

For this class, there are three tools that you should become familiar with right away.

\section{Tool \#1: Create a Skype Account and Chat w/Instructor}

What is it?

Skype is an online communication tool for one-on-one or group conversations. It provides different ways to interact in synchronous and asynchronous formats.

Why use it?

It is free, easy to use, and supports team and group communication and collaboration. If you have Skype already installed on your computer or laptop, then just add me. If you do not have Skype installed, go to http://www.skype.com and download Skype. It’s free.

Directions:

- Go to Skype to download the software. See the Help for Windows users or Help for Mac users if you need help. During the installation process, you'll be asked to create a Skype user name and to add contacts to your contact list. Add me and the students you know to your contact list.

- If you need help, post a message in Course Help discussion topic.

- When you can, begin a text chat with me when you see me online so I will know that you were successful in installing and using Skype. If you don't see me online in Skype, post a message to me in Skype. I'll get back to you ASAP so we can have a voice conversation if possible. It's very fun!

\section{Tool \#2: Create a Gmail Account and Send a Gmail Message}

What is it?

It's an e-mail account offered by Google and includes Gmail, Google Docs, Calendar, Sites, Scholar, and much more. 
Why use it?

Gmail is always available wherever you are, from any device: desktop, laptop, phone, or tablet.

It's always easy to find what you're looking with the power of Google Search right in your inbox

Directions:

- Go to http://gmail.com and click "Create an account” on the right, and follow the directions.

- Send me a Gmail message. My Gmail address is mariammatta76@gmail.com.

\section{Tool \#3: Create a Twitter Account}

What is it?

Twitter is a microblogging service. It allows you to post 140 characters for each "tweet." You can send personal messages to others on Twitter, follow other twitterers, post links to websites, and search tweets by words, tags, and people. You can also see what topics are trending in your geographic location or anywhere in the world.

Why use it?

People use Twitter to communicate with others in concise sentences or phrases. As a teacher, you can follow other teachers who share teaching ideas, researchers in your field, or even your students.

Directions:

- Navigate to http://www.twitter.com.

- Sign up for a free account.

- Complete your Twitter profile. Decide to make your account public or private. Put a picture on your account and add a background image.

- Create a post and at the end add "\#EDUC518." You can use a maximum of 140 characters. See an example of a Twitter account at https://twitter.com/mariammatta. Don't freak out; just do this. If you don't like it, after the course you can delete it.

\section{Appendix B}

\section{Blogging Project}

Overview

Create a blog on Blogger to write on the following topic: why Web 2.0 is good for teaching and learning.

Instructions

- Create an account at http://www.blogger.com, and let me know your blog ID or URL. You may use a pseudonym and limited biographical information to protect your privacy if you wish, but I must be informed of your ID so I can grade your assignment. If you already have a blog, you may either use it here or create a new account specifically for this class.

- Please note that you can use any blogging sites.

- In your blog, write (750-1,000 words) on the following elements:

o Convince your reluctant administrator or colleague that the use of Web 2.0 technologies will enhance students' learning experiences.

o What are examples of Web 2.0 tools being used for student engagement and deep learning?

o In practical day-to-day terms, how would you implement Web 2.0 in a meaningful way that facilitates learning and offers more than just skills in manipulating software?

- Include your personal experiences with Web 2.0 Technologies to support your argument.

- Include references and citations to relevant articles that support your argument. 
- Post the link of your blog in this discussion.

Grading

- Your blog will be assessed using the rubric (20 points).

- Comment in two other students' blogs (10 points).

\section{Appendix C}

\section{Group Work Instructions}

Overview

Using group work is an important strategy for teachers and students for the following reasons:

- Collaboration enhances learning outcomes.

- Group work allows students with different backgrounds to bring their special knowledge, experience, or skills to a project, and to explain their orientation to others.

- Group work gives students a chance to teach each other.

- Collaboration gives students a structured experience so they can practice skills applicable to professional situations.

- For online courses, group work reduces the potential for learner isolation that can occur in the online environment.

\section{Instructions}

In the wiki project, you will be asked to work in a group of three students. To help you create your group, here are some instructions:

- Use the introduction discussion in the Getting Started module and students' contributions on the previous discussions to help you make decisions about who might make good group partners for you.

- Create your group. (Use this tutorial to help you join a group: http://guides.instructure.com/s/2204/m/4212/l/64913-how-do-i-join-a-student-group.)

- $\quad$ Read the Group Work Guide.

- Complete the Group Contract.

- $\quad$ By Nov. 5, have one person from your group submit the link to your group contact.

\section{Appendix D}

\section{Group Work Guide}

\section{Overview}

Using group work is an important strategy for teachers and students. Of course, there are challenges to address and potential roadblocks to avoid. This guide provides resources and examples to help you and your group address the challenges and start out on the right track in the development of your collaborative product.

\section{Establishing Group Policies and Procedures}

As a group you will need to consider the following:

- How will you communicate?

- Will there be a permanent group leader, or will this task be rotated in some way?

- Who will be assigned to post the group's assignment in your discussion area by the due date?

- How often will you be expected to check for updates from your group members? 
Web 2.0 Technologies and Building Online Learning Communities: Students’ Perspectives

- What will be your group's policy on absences?

- What policy will you have in place to resolve intragroup conflict that may arise?

\section{Collaborative Tools}

There are so many collaboration tools available that the biggest problem for groups ends up being reaching an agreement on which tools to use. Here are my recommendations:

- Canvas Group Tools. You have group tools in your course. They will be a great option!

- Skype (http://www.skype.com). Skype is great for free synchronous collaboration allowing text, audio, and video chat. The ability to share files and large chunks of text are excellent features of Skype.

- Google Docs (http://docs.google.com). Google Docs is a great tool for online collaborative writing. It's just like using MS Word, and everyone in your group can edit the same document online at anytime. If you have a Gmail account, you may already have Google Docs as a feature when you log in to your Gmail account. And one thing that is nice for us is that Canvas has a nifty Collaborations feature that integrates with Google Docs.

\section{Appendix E}

\section{Group Contract}

Task: Team building exercise

Objective: To determine the code of contract for a team

Group Members: (Write your group members’ names.)

Instructions

Now that you have determined your group, it is time to determine how your group will operate. A good group code of conduct will include, but is not necessarily limited to, the following items:

1. How will you communicate? Will you post notes and updates for one another in your group discussion area in Canvas? Will you communicate via a mass e-mail list, where anything that one group member sends is received by all? Will you meet in person?

2. How often will you be expected to check for updates from your group members?

3. Will there be a permanent group leader, or will this task be rotated in some way?

4. Who will be assigned to post the group's assignment solution per the due date policy in our syllabus? Will one person be the poster, or will group members take turns posting assignment solutions?

5. What will be your group's policy, if any, on absences and covering for one another if need be?

6. What policy will you have in place to resolve any intragroup conflict that may arise (for example, if a group member neglects to carry out his or her delegated duties to post the assignment on time, or if a group member is not receiving or responding to group updates as often as expected in Item 2 above)?

\section{Appendix F \\ Wiki Project}

\section{Overview}

You and your teammates will contribute to and collaboratively write a wiki about constructivism, technology, and the future of classroom learning. The wiki domain will be organized from a home page 
with subsidiary pages linked to it and to each other, allowing the reader to explore the information generated by the group. Your wiki should contain five pages (About, Constructivism and Technology Integration Discussion, and three other pages of your choice, about constructivism, technology, and the future of classroom learning, of course).

The pages that make up this project should conform to the format described in the Wiki Format page.

\section{Group Dynamics And Individual Responsibility}

- As a group, students will be expected to collaborate extensively in designing the overall product.

- As a group, students will collaboratively write the home page/About page and the Constructivism and Technology Integration Discussion pages. However, each student in the group will be responsible for writing one of the other three pages of the group wiki.

- The group should discuss the organization of the wiki site and decide on a division of the work.

- To allow individual assessment of student effort, each page of the three wiki pages produced will be identified with a single student author, whose name should appear at the bottom of the page.

\section{Instructions}

- One of your group members needs to volunteer to create a wiki (i.e., PBWorks Wiki), invite me (mariammatta76@gmail.com) and your group members (as editors).

- As a group, you are required to create a wiki containing five pages.

- In the home page/About page of your group wiki (worth 20 points):

o The home page should have the subsidiary pages linked to it and to each other, allowing the reader to explore the information generated by the group. See Wiki Format.

0 Write the name of your group.

o Provide an overview about your wiki and its purpose.

o Share the link of your group wiki in this discussion by Nov. 10.

- In the second page of you group wiki (worth 20 points):

0 As a group, discuss your understanding of constructivism and the characteristics of a constructivist classroom.

o Develop an argument for integrating technologies in teaching based on constructivist learning theory.

0 Reference at least three readings.

o Write 750-1,000 words.

o Share the link of your group wiki in this discussion by Nov. 17 .

o Comment on your classmates' wiki. You will not receive a grade for this part until you comment on other students' wikis.

- In the three other pages of your group wiki (worth 20 points for each page):

o Demonstrate through examples how specific educational technologies support the conditions of a constructivist framework for learning.

o Support your argument with the course readings, your own sources, and your experiences as a teacher and a student with technology.

0 Reference at least three readings in each page.

o Write 750-1,000 words in each page.

o Share the link of your group wiki in this discussion by Dec. 1 .

- By Dec. 6, individually do a peer review to at least two of your classmates' wikis by commenting directly in their wikis based on the following guide (worth 40 points):

What I like

(5 points)
What I think could be improved (10 points)
What I have questions or recommendation about (5 points) 


\section{Regarding the Peer Review for the Wiki Project}

You need to directly comment in two of your classmates' wikis. However, only users that appear in the users list of the wiki are able to make comments. Anonymous users, or users that are simply logged in with a PBworks account and not joined to your space, cannot make any comments on any page. It looks like this would require us to add everyone to our username list regardless of if they have a PBworks account or not. I have found that it is not practical to add all of our class members to your wiki, so I created the peer review schedule below.

$\begin{array}{lll}\begin{array}{l}\text { Peer Review Schedule } \\ \text { Group }\end{array} & \text { Peer Review 1 } & \text { Peer Review 2 } \\ \text { Group 1 } & \text { Group 8 } & \text { Group 7 } \\ \text { Group 2 } & \text { Group 8 } & \text { Group 4 } \\ \text { Group 3 } & \text { Group 5 } & \text { Group 6 } \\ \text { Group 4 } & \text { Group 5 } & \text { Group 7 } \\ \text { Group 5 } & \text { Group 4 } & \text { Group 3 } \\ \text { Group 6 } & \text { Group 3 } & \text { Group 2 } \\ \text { Group 7 } & \text { Group 2 } & \text { Group 1 } \\ \text { Group 8 } & \text { Group 1 } & \text { Group 6 }\end{array}$

This means that Group 2 needs to review Groups 4 and 8's wikis and add the members of Groups 6 and 7 to their wiki. Group 4 needs to review Groups 5 and 7's wikis and add Groups 2 and 5 to their wiki, and so on.

\section{Grading}

- Your wiki, with its five pages, is worth 90 points. Each wiki page (except the home page) will be graded based on the wiki rubric.

- Evaluating peer contribution. Each student in the group will evaluate his/her peer contribution based on this rubric.

I will grade the group wiki based on the wiki rubric and based on your peer evaluation to your contribution. For example, if (based on the wiki rubric) your wiki deserves the 60 points and your peers evaluate your contribution as $100 \%$, then your final grade in the wiki project will be $60 / 60$. But if your peers evaluate your contribution as $50 \%$, then your final grade will be $30 / 60$. If your peers' evaluation of your contribution differed (one said that you deserved 100\% while the other peer said you deserved 50\%), in that case I will calculate the mean.

\section{Appendix G}

\section{Reflective Activity}

Reflect on the learning community in this course and how the learning community positively or negatively affected your learning in the course. In your reflection, consider answering the following questions:

- Did using Google Docs give you a sense of a learning community?

- Why did using Google Docs give you a sense of a learning community (or why didn't it)?

Post your reflection by December 8 and reply to each other. You will receive 10 points for posting your reflection and 10 points for responding to at least three other classmates. 